DOI : $10.14746 / \mathrm{pp} .2014 .19 .4 .12$

\title{
Maciej DRZONEK
}

Szczecin

\section{Wielokadencyjność prezydenta miasta po wejściu Polski do UE - przypadek Gdyni}

\begin{abstract}
Streszczenie: Artykuł jest próbą pokazania specyfiki władania prezydenta polskiego miasta wybieranego co najmniej trzykrotnie. W sposób szczególny został wzięty pod uwagę kontekst obecności Polski w strukturach UE. Jako przypadek analizowany w zaprezentowanej analizie wzięto prezydenturę Wojciecha Szczurka w Gdyni. Podstawowe pytanie badawcze określono następująco: czy wielokadencyjność może pozwolić prezydentowi miasta na większe wykorzystanie członkostwa Polski w UE? W artykule zaprezentowano wyniki wyborcze W. Szczurka w elekcjach bezpośrednich przeprowadzanych w Polsce w latach 2002, 2006 i 2010. W celu odpowiedzi na pytanie badawcze przeanalizowano wielkość absorpcji środków unijnych przez Gdynię oraz oceniono znaczenie Listu otwartego do polskich polityków i dziennikarzy. Brońmy polskich interesów (4.02.2014), w którym W. Szczurek poddał krytyce działanie Komisji Europejskiej.
\end{abstract}

Słowa kluczowe: wybory lokalne, prezydent miasta, wielokadencyjność, reelekcje

D rzystapienie Polski do Unii Europejskiej w 2004 r. odbyło się w połowie rozpoczętej w 2002 r. czwartej kadencji organów władzy lokalnej. Wybory samorządowe przeprowadzone w 2002 r. były jednak pierwszymi, w których wójtów gmin oraz burmistrzów i prezydentów miast wybierano wedle ordynacji bezpośredniej (ustawa z 20 VI 2002 r. o bezpośrednim wyborze...). W trakcie dekady polskiego członkostwa w UE jeszcze dwukrotnie przeprowadzono wybory samorządowe - w 2006 r. i 2010 r. Kadencja organów wykonawczych samorządu terytorialnego gmin i miast, która - kończy się w 2014 r. - jest więc trzecią, rozpoczętą w wyniku woli ich mieszkańców wyrażonej w głosowaniu bezpośrednim. Celem niniejszego artykułu jest pokazanie specyfiki władania prezydenta polskiego miasta wybieranego co najmniej trzykrotnie. W sposób szczególny zostanie wzięty pod uwagę kontekst obecności Polski w strukturach UE, a przypadkiem rozpatrzonym w poniższej analizie będzie prezydentura Wojciecha Szczurka w Gdyni ${ }^{1}$. Podstawowym pytaniem badawczym jest próba ustalenia czy wielokadencyjność może pozwolić prezydentowi miasta na większe wykorzystanie członkostwa Polski w UE.

Problematyka wyborów lokalnych, ze szczególnym uwzględnieniem wyborów prezydenckich była już w literaturze przedmiotu analizowana przez wielu badaczy (zob. np.: Antoszewski, 2012; Bukowski, Flis, Hess, Szymańska, 2011; Drzonek, 2013a; Gendźwiłł, 2008; Gendźwiłł, Żółtak, 2012; Flis, 2011; Getimis, Grigoriadou, 2004; Jańczak,

${ }^{1} \mathrm{~W}$ artykule wykorzystane zostaną niektóre wcześniej opublikowane ustalenia badawcze (Drzonek, 2013). 
Musiał-Karg, Secler, 2013; Mossberger, Stoker, 2001; Swianiewicz, Klimska, Mielczarek, 2004; Tomczak, 2012; Wołek, 2008). Problematyka wielokadencyjności została szeroko podjęta w innych badaniach (Drzonek, 2013).

\section{Wielokadencyjność prezydenta miasta - uwagi terminologiczne}

Wielokadencyjność jest tutaj rozumiana jako pewien status, który można osiagnąć w wyniku wyborów bezpośrednich. Polskie ustawodawstwo wyborcze nie przewiduje ograniczeń dotyczących liczby kadencji prezydenta miasta (wójta, burmistrza) wybranego w elekcji bezpośredniej (zob. Kodeks wyborczy...). Za podstawowe kryterium wielokadencyjności przyjęto trzykrotne uzyskanie mandatu prezydenta miasta w kolejnych, następujących po sobie, wyborach bezpośrednich, a więc możliwość zarządzania miastem przez 12 lat. Elekcja, a potem dwukrotna reelekcja na fotel prezydenta miasta jest przejawem nie tylko świadomego poparcia udzielonego przez mieszkańców na rzecz konkretnej osoby piastującej urząd prezydenta miasta, ale stanowi ona wyraźne potwierdzenie aprobaty dla sposobu zarządzania miastem.

Za istotny atrybut wielokadencyjności uznano także sposób zakończenia pełnienia funkcji prezydenta miasta. Przyjęto bowiem, iż wielokadencyjny prezydent miasta nigdy nie przegrywa wyborów, a swój mandat sprawuje „tak długo jak chce”. Wedle tego założenia prezydent taki zarządza miastem do momentu, gdy sam podejmie decyzję o nieubieganiu się o ponowny wybór. Wielokadencyjny prezydent nigdy zatem nie doznaje porażki wyborczej, a swój mandat traci albo z powodów naturalnych, niezależnych i niezawinionych (choroba lub śmierć), albo w wyniku podjęcia świadomej decyzji o zaprzestaniu kandydowania w kolejnych wyborach. Przy czym decyzja taka nie jest podejmowana z powodu przewidywanej porażki, wręcz przeciwnie, jest podjęta pomimo oczekiwania mieszkańców miasta, aby swój mandat dalej realizował. Rezygnacja z ubiegania się o reelekcję może więc być następstwem chęci kontynuowania działalności publicznej na innej płaszczyźnie (parlamentaryzm, działalność ekspercka, praca w rządzie), podjęcia aktywności biznesowej czy też po prostu przejścia na emeryturę. Zakończenie wielokadencyjnej prezydentury jest zatem wynikiem woli samego prezydenta, a nie efektem mniejszego poparcia społecznego.

Należy w tym miejscu zwrócić uwagę, na dwie kwestie. Po pierwsze, co jest oczywiste, w sytuacji przegranej w wyborach, prezydent traci swój wielokadencyjny status. Po drugie, niekiedy trudno ocenić czy rezygnacja ze startu w kolejnej elekcji jest wynikiem obaw przed przegrana, czy też jest skutkiem zamierzenia podjęcia innej aktywności publicznej. Można jednakże w dość prosty sposób ocenić, co jest prawdziwym powodem odstapienia od walki o kolejną kadencję. Jeśli istnieje wysokie prawdopodobieństwo ponownej wygranej w elekcji prezydenckiej (np. poparte wynikami sondażowymi), a pomimo tego prezydent nie zabiega o następną kadencję w magistracie, to w sposób wyraźny bądź dorozumiany wskazuje osobę, którą chciałby zobaczyć jako swego następcę. To swoiste „dokonanie namaszczenia na kontynuatora misji” można uznać za wymierny wskaźnik rzeczywistych przyczyn decyzji o rezygnacji z ubiegania się o kolejną reelekcję. Albowiem prezydent miasta, który kończy kadencję z powodu jej niewystarczających efektów, z niewielkim poparciem wśród mieszkańców, nie zdecyduje 
się na ,akt namaszczenia”, ponieważ byłby on nie tylko bezskuteczny, lecz wręcz przeciwskuteczny ${ }^{2}$.

W Polsce mieszkańcy wybierają prezydentów w 107 miastach, spośród których 66 posiadało status miast na prawach powiatu w trzech bezpośrednich elekcjach ${ }^{3}$. Po wyborach w $2010 \mathrm{r}$. w trzydziestu miastach na prawach powiatu zasiadali prezydenci wielokadencyjni, ponieważ sprawowali oni swoje mandaty co najmniej od 2002 roku.

Podstawową przyczyną wielokadencyjności jest zadowolenie mieszkańców z rządów miastem przez urzędującego prezydenta. Jeśli bowiem, prezydent sprawuje władzę w mieście w sposób, który budzi aprobatę jego mieszkańców, to podczas kolejnej elekcji dadzą oni tego wyraz przy urnach wyborczych. Kluczem do uzyskania reelekcji jest zatem stałe zaspokajanie potrzeb mieszkańców. To tyleż proste, co oczywiste stwierdzenie w praktyce zarządzania miastem nie jest jednak tak łatwe - gdyby było inaczej, to przecież wszyscy prezydenci dokonywaliby reelekcji.

Istnieją jednak pewne przesłanki, które mogą zwiększyć prawdopodobieństwo dokonania kolejnej reelekcji. Jedną z nich jest posiadanie własnego prezydenckiego zaplecza politycznego w Radzie Miasta. Im jest ono większe, tym prezydent może skuteczniej realizować własny program zarządzania miastem.

Wielkość tego zaplecza wpływa również na model sprawowania władzy przez prezydenta. Można wyróżnić trzy jego odmiany: autonomiczny, współzależny oraz zależny. Model autonomiczny to sprawowanie zarządu miastem przy pomocy własnego zaplecza w Radzie Miasta, które posiada w niej większość bezwzględną. Jest to oczywiście sytuacja najbardziej korzystna, ponieważ umożliwia sprawowanie władzy w mieście wyłącznie w oparciu o własnych radnych, a co za tym idzie, pozwala na sprawne zarządzanie miastem, bez konieczności zawierania kompromisów z innymi podmiotami działającymi na miejskiej scenie politycznej. To z kolei umożliwia prezydentowi podejmowanie decyzji zgodnych z oczekiwaniami mieszkańców. Drugi model - współzależny - jest oparty na większości zwykłej w Radzie - wymaga on więc zawarcia koalicji przynajmniej z jednym z podmiotów politycznych zasiadających w niej. Najmniej korzystny jest model trzeci - zależny. W tym przypadku radni prezydenccy stanowią mniejszość w Radzie Miasta. W modelu drugim, a zwłaszcza w trzecim na znaczeniu przybiera kolejny czynnik wspomagający reelekcje - umiejętność budowania koalicji przez prezydenta posiadającego małą liczbę radnych.

Poza wielkością zaplecza i modelem sprawowania władzy, czynnikiem sprzyjającym w przedłużeniu ważności mandatu do sprawowania władzy jest mały poziom rywalizacyjności wyborczej (o rywalizacyjności zob. np. Antoszewski, 2004, s. 34; Gendźwił, 2008, s. 37 ) ${ }^{4}$.

\footnotetext{
${ }^{2}$ Można tu przywołać przykład Mirosława Mikietyńskiego, bardzo popularnego prezydenta Koszalina, wybranego w I turze głosowania w 2002 r. i 2006 r. W 2010 r., tuż przed zakończeniem kadencji 2006-2010, z powodu poważnej, rzadkiej choroby (o której poinformował już w 2008 r.) musiał on ustapić z urzędu. Podjął wówczas decyzję o przekazaniu zarządzania miastem jego sekretarzowi, Piotrowi Jedlińskiemu, który stał się p.o. prezydenta. W 2010 r. P. Jedliński, uważany za „kontynuatora” M. Mikietyńskiego, wygrywając wybory w II turze stał się prezydentem Koszalina.

${ }^{3}$ Warto jednak zaznaczyć, że od $2013 \mathrm{r}$. Wałbrzych ponownie uzyskał status miasta na prawach powiatu, a zatem obecnie jest ich 67.

${ }^{4}$ Wskaźnik intensywności rywalizacji wyborczej jest w niniejszej analizie określany na podstawie różnicy procentowej między dwoma najlepszymi wynikami wyborczymi.
} 
Albowiem im rywalizacyjność między prezydentem a jego głównym kandydatem jest większa, tym różnica w poparciu między nimi posiada mniejszą wartość, a co za tym idzie, dokonanie reelekcji jest trudniejsze. Wpływ na dokonanie reelekcji ma również posiadanie dobrych relacji z liderami opinii (influentials), o których pisał Paul Lazarsfeld (zob. Katz, Lazarsfeld, 2006). Realizacja nawet najbardziej oczekiwanych celów w polityce lokalnej może bowiem okazać się słabo dostrzegana, o ile nie zainteresują się nią influentials (szerzej zob. Watts, Dodds, 2007, s. 441-458).

\section{Specyfika Gdyni i fenomen jej prezydenta}

Gdynia prawa miejskie uzyskała 10 II 1926 r. Według danych Głównego Urzędu Statystycznego na koniec grudnia 2012 r. miasto zamieszkiwało 248726 mieszkańców (Rocznik Demograficzny, 2013). W świadomości mieszkańców Gdyni bardzo utrwalony jest tzw. mit założycielski Gdyni - oto w dwudziestoleciu międzywojennym udało się Polsce wybudować nowoczesny port morski - było to nie tylko osiagnięciem technologicznym, ale i kulturowym. Gdynia stała się przykładem na to, że poprzez rozwój technologiczny można utrwalać polskość nad Bałtykiem. W okresie PRL mieszkańcy Gdyni uchodzili za społeczność o wiele bardziej niezależną niż społeczności innych miast - w Gdyni, pomimo ustroju socjalistycznego przetrwało relatywnie wiele firm prywatnych. Symbolem otwartości miasta jest zaś widok na pełne morze dostępny z samego jego centrum. Takiego atrybutu nie posiada konkurencyjny, znacznie większy Gdańsk. Warto wspomnieć też o pewnej rywalizacji pomiędzy tymi dwoma elementami aglomeracji trójmiejskiej. Jej metaforycznym i nieco żartobliwym ujęciem było hasło reklamowe promowane przez gdyński magistrat: „Wolne miasto Gdańsk i szybka Gdynia”. W istocie, Gdynia po 1990 r. odnotowała bardzo szybki rozwój, który zintensyfikowany został zwłaszcza po 2006 r., czyli rozpoczęciu pierwszej pełnej kadencji prezydenta Szczurka po wejściu Polski do UE.

Miasto po 1990 r. miało dotąd dwóch prezydentów. W dwóch kolejnych elekcjach lat 90. XX w. na prezydenta gdyńska Rada Miasta wybierała Franciszkę Cegielską, osobę w Gdyni niezwykle popularną, nazywaną ,Żelazną Franką", W 1990 r. najmłodszym radnym miejskim został wybrany, wówczas 27-letni, Wojciech Szczurek, który już rok później zaczął pełnić funkcję przewodniczącego Rady Miasta. W 1995 r., a więc na początku swojej drugiej kadencji, prezydent F. Cegielska, podczas jednej z narad z najbliższymi współpracownikami, doceniając zaangażowanie W. Szczurka w pracę na rzecz Gdyni, miała nagle stwierdzić: „Będziesz moim następcą” (Sandecki, kaf, 26.09.2006). W istocie, w 1998 r. na fotelu prezydenta Gdyni nastapiła zamiana - zasiadł na nim W. Szczurek, a F. Cegielska przeszła do samorządu wojewódzkiego, obejmując funkcję przewodniczącej sejmiku pomorskiego.

W. Szczurek, jak już wspomniano wyżej, w trzech kolejnych elekcjach lat 2002, 2006 i 2010, dokonywanych już bezpośrednio przez mieszkańców, był wybierany na prezy-

${ }^{5}$ F. Cegielska w 1997 r. zdobyła mandat poselski, w 1998 r. uzyskała największą liczbę głosów w wyborach do sejmiku pomorskiego, a rok później weszła do rządu Jerzego Buzka, w którym do swojej śmierci w 2000 r. pełniła funkcję ministra zdrowia. 
denta Gdyni, uzyskując niespotykanie wielką w innych miastach na prawach powiatu przewagę nad swoimi konkurentami. Obrazują to wyniki wyborcze zestawione poniżej w tabelach 1-3.

Tabela 1

Wyniki wyborów samorządowych w Gdyni w 2002 r.

\begin{tabular}{||l|l|r|r|r|r|c||}
\hline \multicolumn{1}{|c|}{ Gdynia 2002 } & \multicolumn{3}{c|}{ Wybory prezydenckie } & \multicolumn{3}{c||}{ Wybory do RM } \\
\hline \multicolumn{1}{|c|}{ Listy wyborcze } & \multicolumn{1}{c|}{ kandydat } & glosów & proc. & \multicolumn{1}{c|}{ gl. } & proc. & M=28 \\
\hline KKW SLD-UP & Jarosław Duszewski & 11267 & 13,99 & 14621 & 18,56 & 5 \\
\hline KW LPR & Kazimierz Wilk & 2679 & 3,33 & 5430 & 6,89 & - \\
\hline KW PSL & - & - & - & 429 & 0,54 & - \\
\hline KW Samoobrona & Krzysztof Rasch & 1646 & 2,04 & 3570 & 4,53 & - \\
\hline $\begin{array}{l}\text { KWW Bezpartyjni Gdy- } \\
\text { nia 2010 }\end{array}$ & D. Skwiercz-Kijewska & 2715 & 3,37 & 2909 & 3,69 & - \\
\hline $\begin{array}{l}\text { KWW Naprzód Gdynio! } \\
- \text { Lista Prawicowa }\end{array}$ & - & - & - & 9262 & 11,75 & 2 \\
\hline KWW Samorządność & Wojciech Szczurek & 62208 & 77,26 & 41300 & 52,42 & 21 \\
\hline KWW Unia dla Gdyni & \multicolumn{7}{|c|}{-} & - & - & 1272 & 1,61 & - \\
\hline
\end{tabular}

Źródło: Opracowanie własne na podstawie danych PKW.

W pierwszych wyborach bezpośrednich W. Szczurek otrzymał ponad 3/4 głosów - a jego czterej kontrkandydaci łącznie zdobyli tylko 22,73 proc. poparcia. Wskaźnik rywalizacyjności pomiędzy W. Szczurkiem, a kandydatem SLD-UP wyniósł 63,27. Jednocześnie warto zauważyć, że KWW Samorządność zdobył zdecydowaną większość mandatów radnych (21 z 28). Wyniki takie dały W. Szczurkowi niezwykle solidną podstawę do zarządzania miastem.

Tabela 2

Wyniki wyborów samorządowych w Gdyni w 2006 r.

\begin{tabular}{|c|c|c|c|c|c|c|}
\hline \multirow{2}{*}{$\begin{array}{c}\text { Gdynia } 2006 \\
\text { Listy wyborcze }\end{array}$} & \multicolumn{3}{|c|}{ Wybory prezydenckie } & \multicolumn{3}{|c|}{ Wybory do RM } \\
\hline & kandydat & głosów & proc. & gł. & proc. & $\mathrm{M}=\mathbf{2 8}$ \\
\hline KKW LiD & Marzena Dobrowolska & 5009 & 5,21 & 8517 & 9,03 & - \\
\hline KW PiS & Zb. Kozak & 7200 & 7,49 & 15609 & 16,54 & 5 \\
\hline KW PO & - & - & - & 21047 & 22,30 & 6 \\
\hline $\begin{array}{l}\text { KWW Obywatele - Krwiodawcy } \\
\text { - Społecznicy Gdynianie } 2006\end{array}$ & - & - & - & 858 & 0,91 & - \\
\hline $\begin{array}{l}\text { KWW Samorządność Komitet } \\
\text { W. Szczurka }\end{array}$ & Wojciech Szczurek & 82438 & 85,81 & 46373 & 49,14 & 17 \\
\hline KWW Solidarna Gdynia & Waldemar Rekść & 718 & 0,75 & 1965 & 2,08 & - \\
\hline
\end{tabular}

Źródło: Opracowanie własne na podstawie danych PKW. 
Jak można wyżej zauważyć, w elekcji z 2006 r. W. Szczurek dokonał reelekcji, osiągając jeszcze większe poparcie niż w 2002 r. - wskaźnik rywalizacyjności pomiędzy nim a drugim w kolejności kandydatem PiS wyniósł 78,32. Ugrupowanie prezydenta Szczurka, co prawda otrzymało mniej mandatów, ale ciagle posiadało ich więcej niż połowę (17 z 28), co gwarantowało zarządzanie miastem bez konieczności zawierania koalicji.

Tabela 3

Wyniki wyborów samorządowych w Gdyni w 2010 r.

\begin{tabular}{||l|l|c|c|c|c|c||}
\hline \multicolumn{1}{|c|}{ Gdynia 2010 } & \multicolumn{3}{c|}{ Wybory prezydenckie } & \multicolumn{3}{c||}{ Wybory do RM } \\
\hline \multicolumn{1}{|c|}{ Listy wyborcze } & \multicolumn{1}{|c|}{ kandydat } & glosów & proc. & \multicolumn{1}{c|}{ gl. } & \multicolumn{1}{c|}{ proc. } & M=28 \\
\hline KW PiS & - & - & - & 11668 & 12,90 & 2 \\
\hline KW PO & Wiesław Byczkowski & 5981 & 6,51 & 18791 & 20,78 & 5 \\
\hline KW SLD & Andrzej Różański & 3376 & 3,67 & 6596 & 7,29 & - \\
\hline $\begin{array}{l}\text { KW Stowarzyszenie „Nasza } \\
\text { Gdynia” }\end{array}$ & Jacek Urban & 2235 & 2,43 & 915 & 1,01 & - \\
\hline $\begin{array}{l}\text { KWW Samorządnośćc Ko- } \\
\text { mitet W. Szczurka }\end{array}$ & Wojciech Szczurek & 80345 & 87,39 & 52471 & 58,02 & 21 \\
\hline
\end{tabular}

Źródło: Opracowanie własne na podstawie danych PKW.

Wybory z 2010 r. przyniosły kolejną reelekcję prezydenta Szczurka dokonaną dzięki jeszcze większemu poparciu gdynian - 87,39 proc., choć gwoli ścisłości należy odnotować, że zdobył on o 2093 głosy mniej niż w 2006 r. Zarazem jednak poziom rywalizacyjności pomiędzy prezydentem Szczurkiem a najlepszym z kontrkandydatów okazał się jeszcze mniejszy i wyniósł 80,88. O dużym sukcesie elekcji z 2010 r. świadczył także wynik, który odnotował KWW Samorządność w rywalizacji o mandaty radnych Gdyni. Podobnie jak w 2002 r. komitet ten otrzymał 21 z 28 miejsc w magistracie, otrzymując, co warto podkreślić, ponad 52 tys. głosów co stanowiło poparcie rzędu 58,02 proc. Był to najlepszy wynik tego komitetu spośród trzech elekcji lat 2002-2010. Warto podkreślić sukces wyborczy komitetu W. Szczurka - jest to bowiem przykład na to, że lokalne ugrupowanie pozapartyjne, nawet przy zastosowaniu promującej partie polityczne ordynacji proporcjonalnej, może z powodzeniem zdobywać większość miejsc w Radzie Miasta. KWW Samorządność bez problemu osiągała znacznie większe poparcie od dominujących na polskiej scenie politycznej partii politycznych, nawet PO, która przecież w Trójmieście zawsze posiadała znaczną rzeszę sympatyków. Poparcie osiagane w Gdańsku, Gdyni i Sopocie przez partie polityczne, które w kolejnych elekcjach parlamentarnych zdobywały mandaty poselskie pokazuje tabela 4 .

Jak można zauważyć, Gdynia, w czterech kolejnych wyborach parlamentarnych XXI w. należała do miast, w których PO zawsze uzyskiwała lepszy efekt od rezultatów w skali ogólnopolskiej. Wyniki KWW Samorządność w wyborach do Rady Miasta należy zatem uznać za tym większy sukces. Wydaje się, że wynikał on z dokonań ekipy prezydenta Szczurka, a także z jego podejścia do pracy na rzecz miasta. W swoich publicznych wypowiedziach często mówił: „Moją partia jest Gdynia”. Sformułowanie to wskazywało $\mathrm{z}$ jednej strony na pewną metaforę, ale zarazem w sposób symboliczny pokazywało, iż 


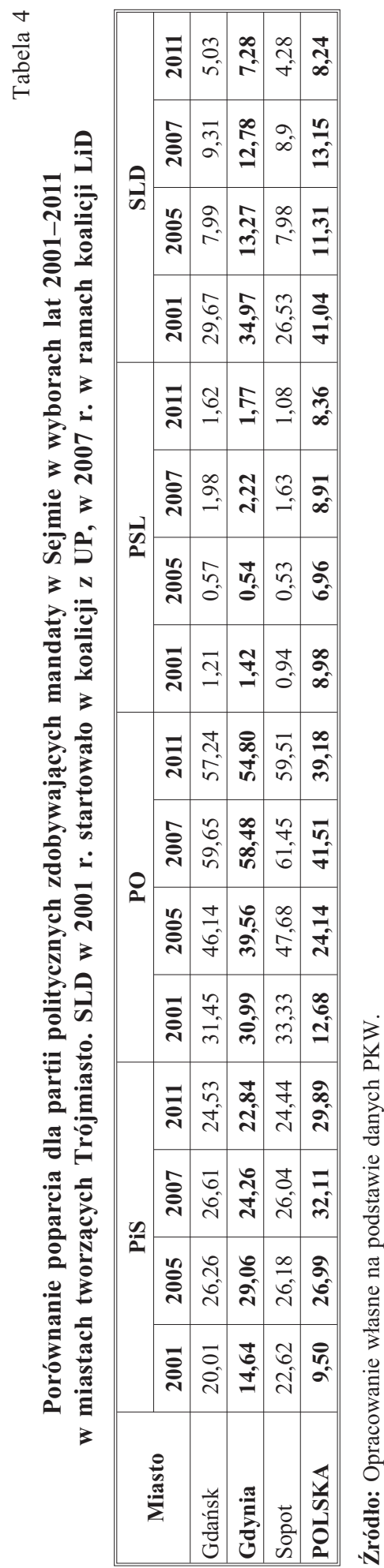


prezydentura W. Szczurka przejmowała pewne funkcje, które zwykle w mieście wielkości Gdyni są atrybutem partii politycznych (Szczurek, 2011).

Efekty rządów W. Szczurka w Gdyni są widoczne w wielu miejscach, a mieszkańcy mogli odczuć ich skutki we własnym życiu codziennym. Już podczas swojej pierwszej kadencji (lata 1998-2002) udało mu się przeprowadzić niezwykle istotne z punktu widzenia każdego dużego miasta inwestycje drogowe i komunikacyjne (m.in. tzw. Węzeł Franciszki Cegielskiej). W tamtym okresie władze miasta położyły również nacisk na realizację celów oświatowych i społecznych, czego przykładem było wprowadzenie tzw. programu szkół otwartych (dzięki niemu mieszkańcy mogli korzystać z infrastruktury sportowej i rekreacyjnej szkół gdyńskich) oraz wybudowanie basenów przyszkolnych (Lewandowski, 2002). W kadencji rozpoczętej w 2002 r. magistrat Gdyński pod kierunkiem W. Szczurka realizował kolejne inwestycje poprawiające poziom życia gdynian - np. Trasa Kwiatkowskiego, hala sportowo-widowiskowa, Muzeum Miasta Gdyni i Marynarki Wojennej, wymiana taboru komunikacji miejskiej (Fryc, 2004; Mazur, 2004). Prowadzono intensywne działania, których celem była poprawa bezpieczeństwa mieszkańców - m.in. za ok. 1,5 mln zł wybudowano i zakupiono wyposażenie Miejskiego Centrum Powiadamiania Ratunkowego, a wraz z początkiem 2003 r. wyasygnowano środki na dodatkowe patrole 30 policjantów (Bauer, 2004). Kadencja kończąca się w 2006 r. przyniosła także utworzenie Pomorskiego Parku Naukowo-Technologicznego, stworzenie nowoczesnego terminalu kontenerowego, a także sukcesy w dziedzinie kultury, m.in. symbolem Gdyni od tego czasu stał się Open'er Festival (Sandecki, Fryc, 2006). Podczas kolejnej kadencji, lat 2006-2010, Gdynia rozpoczęła starania o wybudowanie własnego portu lotniczego (Gdynia-Kosakowo) na terenie powojskowego lotniska w Babich Dołach, co stało się powodem konfliktu z Gdańskiem, który potraktował te aspiracje jako zagrożenie dla płynności funkcjonowania istniejącego przecież lotniska Gdańsk-Rębiechowo (im. Lecha Wałęsy, odległego o ok. 25 km od Kosakowa). Formalnie, plan wybudowania gdyńskiego lotniska został przygotowany pod koniec 2009 r., a we wrześniu kolejnego roku przyszły port lotniczy otrzymał od wojewody gdańskiego decyzję o przekazaniu ponad 250 ha ziemi pod jego budowę. Jakkolwiek można oceniać pomysł budowania lotniska, w odległości ok. $25 \mathrm{~km}$ od już istniejącego innego portu lotniczego, to z pewnością, dla kształtowania tożsamości lokalnej gdynian marzenie to stało się jej ważnym punktem odniesienia (zob. szerzej: Kalendarium, 2013; Tusk, 2010; Szadurski, 2013).

\section{UE w polityce miejskiej Gdyni}

W Polsce już od lat 90. XX w., kiedy III Rzeczpospolita znajdowała się w okresie przedakcesyjnym do Wspólnoty Europejskiej, najbardziej rozpowszechnionym argumentem na rzecz członkostwa w UE był argument finansowy, wskazujący, iż przystąpienie do niej po prostu jest opłacalne pod względem materialnym. Już w okresie znacznie poprzedzającym pełnoprawne członkostwo Polski w strukturach UE w przestrzeni publicznej często posługiwano się szczegółowymi wyliczeniami świadczącymi o tym, że na akcesji do Unii można „zarobić”. Takie myślenie jest udziałem wielu polityków, także tych szczebla regionalnego i lokalnego. Rzeczywiście, sposób wykorzystywania tzw. 
środków unijnych na poprawę infrastruktury państwa polskiego (w różnych dziedzinach jego funkcjonowania) można uznać za pewien wskaźnik opłacalności obecności w UE. W wielu zestawieniach dotyczących bilansu polskiej obecności w UE zwraca się uwagę w zasadzie wyłącznie na ten, łatwo mierzalny aspekt akcesji. Wydaje się jednak, że miarą efektywności członkostwa w jakimś gremium nie jest li tylko to ile można na nim ,zarobić”. Znacznie istotniejszym kryterium oceny jest skuteczność wpływu na proces decyzyjny takiego gremium, ponieważ zaangażowanie w pracę jakiejś instytucji czy organizacji ma sens, o ile pozwala ono na spowodowanie, aby taka instytucja działała zgodnie z naszym interesem. Oczywiście taki wskaźnik ma charakter niekiedy niematerialny, a z pewnością jest on trudniejszy do zweryfikowania.

Czy członkostwo Polski w UE pozwala na realizację materialnego interesu gmin i miast? Odpowiedź na takie pytanie jest oczywiście twierdząca, a jej weryfikacja nie jest trudna - łatwo sprawdzić, kto i ile środków unijnych potrafił absorbować. Czy jednostki samorządowe mogą wpływać na kreowanie polityki UE? Na tak postawione pytanie nasuwa się raczej odpowiedź negatywna. Jednak przykład działań podjętych przez prezydenta W. Szczurka w sprawie lotniska Gdynia-Kosakowo pokazuje, że charakter tej odpowiedzi wcale nie musi być taki oczywisty, jak wydawać by się to mogło pierwotnie.

Zaangażowanie Gdyni w zdobywanie środków finansowych pochodzących z różnych programów UE obrazują dane zebrane w tabeli 5.

Tabela 5

Wykorzystanie funduszy UE przez Gdynię

\begin{tabular}{||l|c|c||}
\hline \multicolumn{1}{|c|}{ Fundusze UE } & Dofinansowanie w euro & Liczba projektów \\
\hline Przedakcesyjne & 46046105 & 30 \\
\hline 2004-2006 & 64723711 & 47 \\
\hline 2007-2013 (zakończone) & 83234660 & 78 \\
\hline 2007-2013 (w toku) & 89328915 & 47 \\
\hline Razem & $\mathbf{2 8 3 ~ 3 3 3 ~ 3 9 1}$ & $\mathbf{2 0 6}$ \\
\hline
\end{tabular}

Źródło: Opracowanie własne na podstawie: Projekty gdyńskie wspólfinansowane ze środków UE w latach 1994-2013. Podsumowanie, http://www.gdynia.pl/wszystko/o/gdyni/euro/pie/7015_.html, 16 VII 2013.

Z powyższego zestawienia wynika, iż Gdynia skutecznie realizowała politykę absorbowania pomocy finansowej UE, zarówno w okresie przedakcesyjnym, jak i w warunkach członkostwa Polski w UE. Widać również, że po akcesji do UE, miasto korzystało w coraz większym stopniu z pomocy unijnej. Warto wspomnieć, że właśnie dzięki wsparciu unijnemu w Gdyni finansowano w znacznej mierze wiele inwestycji już na początku polskiego uczestnictwa w UE: np. otrzymano 15 mln euro na rozbudowę ul. J. Wiśniewskiego i rozwój komunikacji trolejbusowej (Fryc, 2004, Mazur, 2004).

Zupełnie nowego wymiaru zyskała prezydentura W. Szczurka kiedy zaczął on nie tylko angażować podległe sobie służby miejskie w pozyskiwanie środków z pomocy unijnej, ale gdy zaczął prowadzić coś, co można określić, mianem własnej, gdyńskiej polityki unijnej. Dla Gdyni pierwszej dekady XXI w. jednym z priorytetów innowacyjno-rozwojowych było bowiem wybudowanie wspomnianego wyżej lotniska Gdynia-Kosakowo. Kiedy pojawiły się przewidywania, że port lotniczy będzie musiał zwrócić pomoc pub- 
liczną, którą otrzymał od miasta, to głos zabrał prezydent Gdyni. Warto w tym miejscu bowiem podkreślić, że Gdynia próbowała doprowadzić do zakończenia inwestycji bez uciekania się do źródeł finansowych UE.

W tym kontekście, list otwarty prezydenta Szczurka (Szczurek, 2014) opublikowany 4 II 2014 r. stał się zatem wyraźnym przykładem prowadzenia samodzielnej polityki Gdyni wobec UE. Prezydent Szczurek pisał: „Rozpoczyna się kampania do Parlamentu Europejskiego. Przedmiotem debaty publicznej w najbliższych miesiącach będzie miejsce, rola i interesy Polski w Europie. Chciałbym zaapelować do Państwa o wspólną akcję w obronie naszych polskich strategicznych interesów. Wstapiliśmmy do Unii Europejskiej i to przyniosło nam wiele korzyści, ale także doświadczenie, że coraz częściej stajemy się także przedmiotem brutalnej gry i bezwzględnego narzucania Polsce rozwiązań niekorzystnych dla jej przyszłości. [...] Czy energii Polaków nie można byłoby spożytkować lepiej, niż do przezwyciężania szkód czynionych narodowym interesom w imię wybiórczo rozumianej ochrony wolnego rynku?” I dalej dodawał: „Kocham Gdynię i Polskę i wiem, że gdyby obecne regulacje wprowadzane przez Komisję Europejską obowiązywały 80 lat temu, nigdy nie powstałby port i miasto Gdynia, które stały się symbolem polskiego myślenia i działania strategicznego, mającego na celu budowanie siły i sukcesu gospodarczego Polski. Projekt Eugeniusza Kwiatkowskiego, do którego trzeba było w pierwszych latach dopłacać, zostałby uznany za niedozwoloną pomoc publiczną".

List ten spotkał się z odzewem - np. prezydent Gdańska P. Adamowicz zarzucił W. Szczurkowi, że patrzy na interes Polski przez możliwość realizacji własnych aspiracji. W podobnym duchu komentowała list trójmiejska redakcja „Gazety Wyborczej” (zob. Adamowicz, 2014; Katka, 2014).

Obawy prezydenta Gdyni potwierdzily się, ponieważ 12 II 2014 r. Komisja Europejska poinformowała, że „środki publiczne przekazane przez gminy Gdynia i Kosakowo na rzecz portu lotniczego Gdynia-Kosakowo przyznają beneficjentowi nienależną przewagę konkurencyjną, w szczególności nad lotniskiem w Gdańsku, co stanowi naruszenie unijnych zasad pomocy państwa” i ,aby przywrócić sytuację, która panowała na rynku przed udzieleniem pomocy, port lotniczy Gdynia-Kosakowo ma zwrócić nienależnie wypłacone środki w kwocie 21,8 mln euro (91,7 mln złotych)" (Komisja Europejska, 2014). Po tej decyzji Komisji Europejskiej prezydent Gdyni zapowiedział, że ją zaskarży.

\section{Wnioski}

Prezydentura W. Szczurka w Gdyni jest z pewnością przykładem wielokadencyjności zbudowanej na ustawicznej pracy na rzecz lokalnej społeczności municypalnej. Analizując ten swoisty casus prezydenta średniej wielkości miasta polskiego - trudno znaleźć przypadek innego prezydenta, który w trzech kolejnych elekcjach, wygrywając w I turze, osiagałby coraz lepszy rezultat, przy poparciu ponad 3/4 mieszkańców.

W kontekście polskiej, trwającej już dekadę, obecności w strukturach UE, Gdynia i jej włodarz jawią się równie specyficznie. Z jednej strony miasto ma spore osiągnięcia w absorbowaniu środków pomocowych UE. Pod tym względem można oczywiście znaleźć wiele przykładów miast i gmin, które potrafią zadbać o właściwe skorzystanie z dziejowej szansy, jaką dała akcesja do UE. Z drugiej jednak strony - i na tym polega oryginal- 
ność wielokadencyjnej prezydentury W. Szczurka - Gdynia, ustami swojego włodarza, nie waha się wskazać krytycznych uwag co do zasad funkcjonowania UE i tym samym spróbować przynajmniej wywrzeć wpływ na podejmowane decyzje przez jej instytucje. Abstrahując bowiem od rozstrzygania, czy Trójmiasto potrzebuje dziś dwóch lotnisk, można poczynić dwa kolejne wnioski.

$\mathrm{Z}$ pewnością bezprecedensowy list otwarty, który opublikował prezydent Gdyni nie powstałby, gdyby nie miał on pewności co do słuszności sprawy, w której zabrał głos $\mathrm{i}$ - co więcej - gdyby nie czuł on poparcia większości gdynian w tej kwestii. Innymi słowy, to wielokadencyjność wynikająca z silnego poparcia społecznego zapewne umożliwiła zajęcie tak jednoznacznej oceny funkcjonowania UE. Silna pozycja wielokadencyjnego prezydenta miasta pozwala bowiem na skuteczną realizację interesu jego mieszkańców nie tylko na linii władza lokalna - władza państwowa, lecz umożliwia również podjęcie próby rywalizacji o sprawy miasta na forum unijnym.

Wreszcie, dążenie do utworzenia portu lotniczego w Gdyni i podjęcie debaty na ten temat na forum międzynarodowym, zdecydowanie się na krytyczną ocenę działań Komisji Europejskiej, świadczy o pewnym wizjonerstwie prezydenta Szczurka. Zarazem to wizjonerstwo z pewnością pozwoliło również na jego, tak wyraźnie potwierdzaną w kolejnych bezpośrednich elekcjach, wielokadencyjność.

\section{Bibliografia}

Adamowicz P. (2004), My walczyliśmy o infrastrukturę, Szczurek o rejsowe samoloty, trójmiasto.gazeta.pl, 6.02.2014, http://trojmiasto.gazeta.pl/trojmiasto/1,35636,15413405,Adamowicz_My_walczylismy_o_infrastrukture_Szczurek.html, 6.02.2014.

Antoszewski A. (2004), Wzorce rywalizacji politycznej we współczesnych demokracjach europejskich, Wyd. UWr., Wrocław.

Antoszewski A. (2012), Rywalizacja o władzę w miastach Dolnego Ślaska w latach 2002-2010. Uwagi wprowadzajace, w: Rywalizacja o prezydenturę w miastach Dolnego Ślaska, red. D. Skrzypiński, Marina, Wrocław.

Bauer P. (2004), Bezpieczna Gdynia tylko w centrum, „GW Trójmiasto” z dnia 7.12.2004 r.

Bukowski M., Flis J., Hess A., Szymańska A. (2011), Opcja czy osoba? Upartyjnienie versus personalizacja w wyborach samorzqdowych, Wyd. UJ, Kraków.

Drzonek M. (2013), Reelekcje prezydentów miast w wyborach bezpośrednich, Dante, Kraków.

Drzonek M. (2013a), Zdobywanie władzy w mieście - efektywność strategii ,, wiecznego prezydenta”, „Management and Business Administration. Central Europe”, nr 1.

Flis J. (2011), Partie polityczne w wyborach prezydentów miast, „Studia Politologiczne”, nr 20.

Fryc K. (2004), W co inwestuje Gdynia, „GW Trójmiasto” z dnia 22.09.2004 r.

Gendźwiłł A. (2008), Dlaczego sukces? Analiza wyników wyborów prezydentów największych polskich miast, w: Studia nad wyborami. Polska 2005-2006, red. J. Raciborski, Scholar, Warszawa.

Gendźwiłł A. (2010), Bezpartyjni prezydenci miast i ich znaczenie dla lokalnej polityki, „Studia Regionalne i Lokalne", nr 2.

Gendźwiłł A., Żółtak T. (2012), Bezpartyjność w powolnym odwrocie. Analiza rozpowszechniania bezpartyjności $w$ wyborach lokalnych $w$ Polsce w latach 2002-2010, „Studia Regionalne i Lokalne", nr 1. 
Getimis P., Grigoriadou D. (2004), Changes in Urban Political Leadership. Leadership Types and Styles in the Era of Urban Governance, w: Democratic Choices for Cities, red. M. Haus, H. Heinelt, M. Stewart, Routledge, London.

Jańczak J., Musiał-Karg M., Secler B. (2013), Wybory samorzqdowe na Ziemi Lubuskiej, Pomorzu $i$ wielkopolsce. Granice historyczne i relacje centra-peryferia a zachowania wyborcze, Adam Marszałek, Torun.

Kalendarium, 12.03.2013, http://airport.gdynia.pl/kalendarium,airport.gdynia.pl, 12.03.2013.

Katka K. (2014), Dlaczego prezydent Szczurek wietrzy antypolski spisek? [ODPOWIEDŹ NA LIST], trójmiasto.gazeta.pl, 5.02.2014, http://trojmiasto.gazeta.pl/trojmiasto/1,35636,15399302,Dlaczego_prezydent_Szczurek_wietrzy_antypolski_spisek_html\#TRrelSST, 5.02.2014.

Katz E., Lazarsfeld P. F. (2006), Personal Influence. The Part Played by People in the Flow of Mass Communications, Transaction Publishers, New Brunswick-New Jersey.

Kodeks wyborczy, Dz. U. 2011, Nr 21, poz. 113.

Komisja Europejska. Przedstawicielstwo w Polsce (2014), Gdynia-Kosakowo: pomoc do zwrotu, ec.europa.eu, 12.02.2014, http://ec.europa.eu/polska/news/140212_gdynia_kosakowo_pl.htm, 12 II 2014.

Lewandowski M. (2002), Wierzę we własny sukces. Rozmowa z Wojciechem Szczurkiem, prezydentem Gdyni, „GW Trójmiasto” z dnia 7.10.2002 r.

Mazur P. (2004), Dwa lata z Wojciechem Szczurkiem, „GW Trójmiasto” z dnia 6.12.2004 r.

Mossberger K., Stoker G. (2001), The Evolution of Urban Regime Theory. The Challenge of Conceptualization, „Urban Affairs Review”, vol. 36, nr 6.

Rocznik Demograficzny (2013), Główny Urząd Statystyczny, Warszawa.

Sandecki M., Fryc K. (2006), Szczurek znów wygra wyścig, „GW Trójmiasto” z dnia 26.09.2006 r.

Sandecki M., kaf (2006), Gdynia pod rządami Wojciecha Szczurka, „Gazeta Wyborcza. Trójmiasto”, 26.09.2006, http://www.trojmiasto.pl/wiadomosci/Gdynia-pod-rzadami-Wojciecha-Szczurka-n20719.html, 26 IX 2006.

Swianiewicz P., Klimska U., Mielczarek A. (2004), Nierówne koalicje - liderzy miejscy w poszukiwaniu nowego modelu zarzadzania rozwojem, Warszawa.

Szadurski Sz. (2013), Konflikt o lotniska między Gdańskiem a Gdyniq. Czy jest możliwe porozumienie? Kto na tym traci?, gdynia.naszemiasto.pl, 19.04.2013, http://gdynia.naszemiasto.pl/artykul/1820429,konflikt-o-lotniska-miedzy-gdanskiem-a-gdynia-czy-jest,id,t.html, 19.04.2013.

Szczurek W. (2011), Moja partia jest Gdynia!, „Rzeczpospolita” z dnia 3.03.2011 r.

Szczurek W. (2014), List otwarty do polskich polityków i dziennikarzy. Brońmy polskich interesów, gdynia.pl, 4.02.2014, http:/www.gdynia.pl/wydarzenia/70_91499.html?page=5, 4.02.2014.

Tomczak Ł. (red.) (2012), Prezydenci miast. Analiza rywalizacji w wyborach samorzadowych, Marina, Wrocław.

Tusk M. (2010), Każdy chciatby polatać, „GW Gdańsk”, z dnia 12.03.2010.

Ustawa z 20 VI 2002 r. o bezpośrednim wyborze wójta, burmistrza i prezydenta miasta, Dz. U. 2002, $\mathrm{Nr}$ 13, poz. 984; 2010, Nr 176, poz. 1191.

Watts D. J., Dodds P. S. (2007), Influentials, Networks and Public Opinion Formation, „Journal of Consumer Research", vol. 34.

Wołek A. (red.) (2008), Władza i polityka lokalna. Polskie wybory samorzqdowe, Ośrodek Myśli Politycznej - WSB NLU, Kraków-Nowy Sącz.

Wróbel S. (red.), (2008), Samorzad miejski. Zadania, instytucje, formy, Poznań-Chorzów. 


\title{
Multi-incumbency of the mayor of city after Poland's accession in the EU. The case of Gdynia
}

\begin{abstract}
Summary
The article is an attempt to show the specificity mayor of Polish city who is in term of office for at least three times. The analysis is based on the case of president Wojciech Szczurek from Gdynia who had been elected with great majority in direct elections. The context of Poland's presence in EU structures was one of the most important in this analysis. The basic research question is as follows: if the mayor of town's multi-incumbency may allow for greater use of Polish membership in the EU? The article presents the W. Szczurek's results in direct elections conducted in Poland in the years 2002, 2006 and 2010. The comparison of the Gdynia's absorption of EU funds was also examined, as well as the importance of "The Open Letter to the Polish Politicians and Journalists. Lets Defend Polish Interests" (4 $4^{\text {th }}$ Feb, 2014). In this text W. Szczurek criticized some European Commission's actions in Poland.
\end{abstract}

Key words: local elections, mayor of the city, multi-incumbency. 
